\title{
Design catalogue for eco-engineering of coastal artificial structures: a multifunctional approach for stakeholders and end-users
}

\author{
Kathryn A. O'Shaughnessy ${ }^{1}$ (D) - Stephen J. Hawkins ${ }^{2,3}$ - Ally J. Evans ${ }^{2,3,4} \cdot$ Mick E. Hanley $^{5} \cdot$ Paul Lunt ${ }^{1}$. \\ Richard C. Thompson ${ }^{5}$ - Robert A. Francis ${ }^{6}$ - Simon P. G. Hoggart ${ }^{7}$. Pippa J. Moore ${ }^{4}$ Gregorio Iglesias $^{8}$. \\ David Simmonds ${ }^{8} \cdot$ James Ducker $^{5} \cdot$ Louise B. Firth $^{5}$
}

Published online: 28 December 2019

(C) The Author(s) 2019

\begin{abstract}
Coastal urbanisation, energy extraction, food production, shipping and transportation have led to the global proliferation of artificial structures within the coastal and marine environments (sensu "ocean sprawl"), with subsequent loss of natural habitats and biodiversity. To mitigate and compensate impacts of ocean sprawl, the practice of ecoengineering of artificial structures has been developed over the past decade. Eco-engineering aims to create sustainable ecosystems that integrate human society with the natural environment for the benefit of both. The science of eco-engineering has grown markedly, yet synthesis of research into a user-friendly and practitioner-focused format is lacking. Feedback from stakeholders has repeatedly stated that a "photo user guide" or "manual" covering the range of eco-engineering options available for artificial structures would be beneficial. However, a detailed and structured "user guide" for eco-engineering in coastal and marine environments is not yet possible; therefore we present an accessible review and catalogue of trialled eco-engineering options and a summary of guidance for a range of different structures tailored for stakeholders and end-users as the first step towards a structured manual. This work can thus serve as a potential template for future eco-engineering guides. Here we provide suggestions for potential eco-engineering designs to enhance biodiversity and ecosystem functioning and services of coastal artificial structures with the following structures covered: (1) rock revetment, breakwaters and groynes composed of armour stones or concrete units; (2) vertical and sloping seawalls; (3) over-water structures (i.e., piers) and associated support structures; and (4) tidal river walls.
\end{abstract}

Keywords Biodiversity · Coastal management · Ecological engineering · Green infrastructure · Ocean sprawl · Nature-based solutions

Electronic supplementary material The online version of this article (https://doi.org/10.1007/s11252-019-00924-z) contains supplementary material, which is available to authorized users.

Kathryn A. O'Shaughnessy

kathryn.oshaughnessy@plymouth.ac.uk

1 School of Geography, Earth and Environmental Science, University of Plymouth, Plymouth PL4 8AA, UK

2 Ocean and Earth Science, University of Southampton, National Oceanography Centre Southampton, Southampton SO17 3ZH, UK

3 The Marine Biological Association of the UK, The Laboratory, Citadel Hill, Plymouth PL1 2PB, UK
Institute of Biological, Environmental and Rural Sciences, Aberystwyth University, Aberystwyth SY23 3DA, UK

5 School of Biological and Marine Sciences, University of Plymouth, Plymouth PL4 8AA, UK

6 Department of Geography, King's College London, Strand, London WC2R 2LS, UK

7 British Ecological Society, Charles Darwin House, London WC1N 2JU, UK

8 School of Engineering, University of Plymouth, Plymouth PL4 8AA, UK 


\section{Introduction}

Coastlines worldwide are becoming increasingly vulnerable to flooding, erosion and degradation due to rising sea level, stormier seas and increased coastal urbanisation (McGranahan et al. 2007; Halpern et al. 2008; Tessler et al. 2015). The human population within $100 \mathrm{~km}$ of the coastline is disproportionally higher compared to inland areas (Small and Nicholls 2003; McGranahan et al. 2007), with much of this population concentrated in densely packed urban areas (Firth et al. 2016a; Todd et al. 2019). Consequently, coastlines globally have been developed to support human activity, resulting in the drastic and irreversible modification of natural systems (Vitousek et al. 1997; Halpern et al. 2008; Knights et al. 2015). Human activities focused along the coast, such as shipping and transportation, residential and commercial development, as well as the creation of hard artificial defence structures (i.e., seawalls, breakwaters, groynes) to protect valuable urban infrastructure (i.e., utilities, roads, buildings) from rising and stormier seas, have contributed to "ocean sprawl." Ocean sprawl (sensu Duarte et al. 2012) describes the proliferation of artificial structures in marine and coastal environments, and the subsequent modification and loss of natural substrata (Duarte et al. 2012; Firth et al. 2016a; Bishop et al. 2017; Heery et al. 2017). For example, $14 \%$ of coastal United States is composed of hard urban structures (Popkin 2015), $10 \%$ of the Great Barrier Reef World Heritage Area in Australia is armoured (Waltham and Sheaves 2015) and $60 \%$ of the natural coastline in China has been replaced by seawalls (Ma et al. 2014).

Urban infrastructure alters the physical, chemical and biological environment of the receiving ecosystem (Dugan et al. 2011; Firth et al. 2016a; Todd et al. 2019). Hard artificial defence structures (hereafter 'artificial structures') directly replace natural habitats (Airoldi and Beck 2007; Govarets and Lauwaert 2009), resulting in habitat fragmentation (Krauss et al. 2010) and disruption of ecological connectivity (Firth et al. 2016a; Bishop et al. 2017). Additionally, urban infrastructure changes the geomorphology and hydrodynamics of the surrounding habitats (Dugan et al. 2008; Nordstrom 2014). For example, in sandy bottom habitats, artificial structures alter normal wave activity and subsequently affect longshore transport and sediment deposition, modifying the morphology of the coastline (Dugan et al. 2011; Del Río et al. 2013; Nordstrom 2014). Impermeable surfaces that are a common feature of urban systems, such as roads and buildings, increase runoff into the adjacent body of water (Arnold Jr and Gibbons 1996; Barnes et al. 2001), often facilitating increased input of nutrients and pollutants (e.g., agricultural fertilizers, heavy metals; Arnold Jr and Gibbons 1996; Wicke et al. 2012). Fewer organisms in terms of numbers and abundances of species (i.e., biodiversity) colonise coastal urban infrastructure compared to natural habitats in similar environmental settings (Connell 2001; Bulleri and Chapman 2004; Moschella et al. 2005; Lai et al. 2018). This is attributed to the steep profiles and reduced surface area and topographic complexity of urban artificial structures (Knott et al. 2004; Moschella et al. 2005; Chapman and Underwood 2011; Lai et al. 2018). Many artificial structures are dominated by invasive species (organisms that are not native to the ecosystem) and opportunistic species (organisms that make up the initial stages of succession) compared to natural habitats (Glasby et al. 2007; Dafforn et al. 2009, 2012). As a result, the ecological functioning (i.e., biotic processes such as water filtration and primary productivity) of artificial structures is often different to comparable natural habitats (Mayer-Pinto et al. 2018a; b). Changes in ecological functioning can have detrimental knock-on effects on the provision of 'ecosystem services' - desirable secondary benefits to both society and nature, such as improvement in water quality, increase in carbon sequestration and more space for outdoor recreational activities (Fig. 1).

Regardless of the specific ecological impacts, it is clear that human actions are leading to the development of new habitats and ecosystems without natural analogues ('novel ecosystems'; Hobbs et al. 2006; Morse et al. 2014). In response, some ecologists are considering how to manage these new

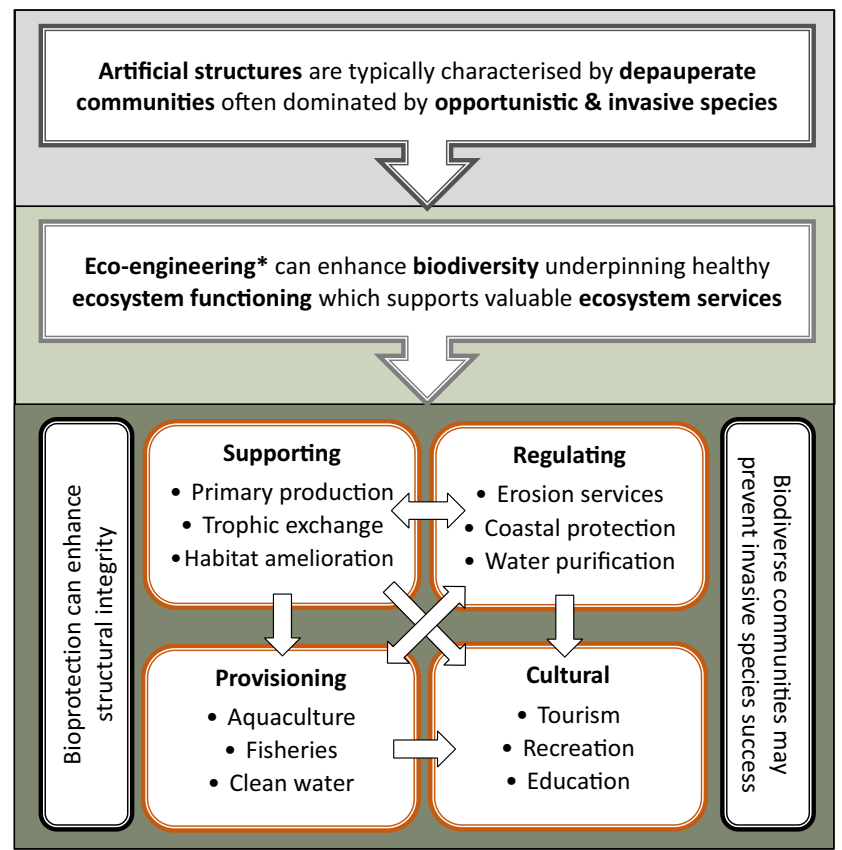

Fig. 1 Typical characteristics of artificial structures and how ecoengineering optimises the potential ecosystem services as outlined by the Millennium Ecosystem Assessment (red boxes) (Millennium Ecosystem Assessment 2005; Everard 2017). The arrows show the potential linkages and feedbacks between services (e.g., improved fisheries [provisioning service] can have beneficial knock-on effects to recreational fishing and tourism [cultural service]). Other potential desirable outcomes of eco-engineering are highlighted in black boxes. *Eco-engineering enhances biodiversity and ecosystem services only compared to the ecological condition of the same structure without eco-engineering applications 
habitats for ecological and societal benefit (Milton 2003; Hobbs et al. 2006; Macdonald and King 2018). The design of such ecosystems, which integrate human society with the natural environment for the benefit of both, has been labelled ecological engineering (or "eco-engineering"; Odum 1962; Mitsch and Jorgensen 1989; Odum and Odum 2003). Whilst the environmental context of artificial structures is likely to be fixed (e.g., tidal position, geographic position), their associated biodiversity (i.e., the variety of living organisms; Colwell 2009) and role in ecological functioning can be enhanced through eco-engineering techniques.

The field of eco-engineering is beginning to provide practitioners, developers, managers and decision makers with options for the design and management of artificial structures in the coastal and estuarine environments to support biodiversity and provide desirable ecosystem services (Fig. 1) whilst not compromising the primary function of a structure (e.g., coastal defence, safe berthing in a port). As coastal urbanisation intensifies, the pressure on coastal developers to incorporate ecologically sensitive designs will undoubtedly increase. Recently, there has been increasing impetus among stakeholders for eco-engineering of artificial structures to support ecosystem services. Evans et al. (2017) interviewed different stakeholder groups about their perceptions of artificial coastal defence structures and their potential to provide built-in secondary benefits. Respondents prioritised ecological benefits over economic, social and technical ones. At the same time, stakeholders have raised concerns relating to the impacts of eco-engineering interventions; engineers are concerned with impacts on the performance and durability of the structure whilst conservationists are concerned about invasive species (Dafforn et al. 2012; Evans et al. 2017; Naylor et al. 2017). Research has shown that the encouragement of certain colonising organisms such as barnacles, mussels, oysters and algae can have a positive "bioprotective effect" through physical strengthening of the materials and protection from temperature extremes and wave action (Risinger 2012; Coombes et al. 2013; Coombes et al. 2015). Furthermore, one of the primary functions of eco-engineering is to promote diverse native biological communities that can prevent the establishment of invasive species (Stachowicz et al. 1999; Stachowicz et al. 2002; Arenas et al. 2006b; Fig. 1).

Whilst efforts should be focused on maximising ecological benefits through eco-engineering of artificial structures, the best option is to allow natural biogenic habitats and defences to persist where possible and avoid building artificial structures unless absolutely necessary - the "do nothing" approach (Hoggart et al. 2014). Where and when human intervention is needed for reasons of public safety, infrastructure protection or energy development, the use of "soft" engineering approaches should be prioritised if possible (Dafforn et al. 2015a; Morris et al. 2018a). These interventions typically involve working with nature, such as the modification or removal of artificial structures to allow the sea to re-inundate previously reclaimed land (commonly called "managed realignment"; French 2006; Masselink et al. 2017; MayerPinto et al. 2017), or using vegetation, sand-fills and sand nourishment as coastal protection (Stive et al. 2013; Hanley et al. 2014; Morris et al. 2018a). Where these soft designs are not possible, a combination of hard and soft techniques, such as "hybrid stabilisation" and "living shorelines" approaches, should be considered (Bilkovic and Mitchell 2013; SuttonGrier et al. 2015; Polk and Eulie 2018). Quite often in urbanised areas, however, the only feasible approach is to build hard structures due to lack of space and the immediate need to protect valuable urban infrastructure (Chee et al. 2017). In this paper, we assume that the reader has already explored and rejected soft engineering options, leading to an informed decision to move forward with necessary ecoengineering of hard structures to provide secondary functional benefits.

Feedback from stakeholders and end-users has repeatedly informed us that a "photo user guide" or "manual" covering the range of eco-engineering options available would be much easier than having to sift through the rapidly expanding body of academic literature (see Dafforn et al. 2015a; Geist and Hawkins 2016; Mayer-Pinto et al. 2017 for reviews). It is increasingly accepted that one role of scientists and engineers is to inform coastal managers and government bodies of current research (Chapman and Underwood 2011; Evans et al. 2017). Thus, structured guides and frameworks (e.g., Mayer-Pinto et al. 2017; Naylor et al. 2017) tailored for decision-makers will become essential for eco-engineering to progress. Therefore, in this paper, we provide a user-friendly, illustrated review of trialled eco-engineering options and a summary of potential guidance for a range of different artificial structures for practitioners involved in the development of coastal environments. This work can thus serve as a template or model for future eco-engineering guides and frameworks that should evolve in tandem with emerging proof-of-concept evidence. Here, various types of structures are considered in turn, with guidance given on appropriate eco-engineering interventions (Supplementary Information Tables 1-4), and generic and contextual considerations on application of eco-engineering designs are discussed.

\section{Methods}

\section{Literature search}

Using literature identified by Strain et al. (2017a) as a foundation and supplemented with subsequent searches for scientific articles, conference papers and government 
reports, we reviewed studies and projects on ecoengineering interventions in coastal, estuarine and tidal river systems from around the world that included measurable ecological outcomes (e.g., biodiversity, ecosystem services). We focussed only on measurable ecological effects because the vast majority of eco-engineering studies measured only these outcomes, although social, cultural and economic knock-on effects are expected (Fig. 1; Airoldi et al. 2005). Results from the literature search are displayed in Table 1 as intervention types for each category of artificial structure, including the number of studies that has tested each intervention (as a proxy for evidence base). We then selected studies from the literature search that we felt represented the range of options for the most common types of structures and presented these as separate tables for each type in a visual framework included in the Supplementary Information (see below for descriptions of structures). Information for each selected study includes design details, intended outcomes, success, photographs,

Table 1 Summary of eco-engineering intervention studies reviewed for each artificial structure type. Interventions are described below and examples are provided in Supplementary Information Tables 1-4. Studies

\begin{tabular}{|c|c|c|}
\hline Artificial structure type & Eco-engineering intervention & No. of studies \\
\hline \multirow{6}{*}{$\begin{array}{l}\text { Rock revetment, breakwaters and groynes made of armour stones or concrete units } \\
\text { (see SI Table 1) }\end{array}$} & Hybrid stabilisation & 20 \\
\hline & Pits, holes, crevices, grooves, cuts, roughness, gaps & 5 \\
\hline & Precast habitat enhancement units & 3 \\
\hline & Rock/tidal pools & 4 \\
\hline & Seeded, textured or complex tiles or panels & 3 \\
\hline & Transplant target species & 5 \\
\hline \multirow{8}{*}{$\begin{array}{l}\text { Vertical and sloping seawalls } \\
\text { (see SI Table 2) }\end{array}$} & Addition of natural material & 1 \\
\hline & Gabion baskets & 2 \\
\hline & Hybrid stabilisation & 1 \\
\hline & Modifying seawall slope or seawall removal & 4 \\
\hline & Pits, holes, crevices, grooves, cuts, roughness, gaps & 5 \\
\hline & Rock/tidal pools & 7 \\
\hline & Seeded, textured or complex tiles or panels & 8 \\
\hline & Transplant target species & 2 \\
\hline \multirow{2}{*}{$\begin{array}{l}\text { Over-water structures } \\
\text { (see SI Table 3) }\end{array}$} & Light-penetrating designs & 7 \\
\hline & Seeded, textured or complex tiles or panels & 2 \\
\hline \multirow{4}{*}{$\begin{array}{l}\text { Pier pilings } \\
\text { (see SI Table 3) }\end{array}$} & Addition of synthetic material & 1 \\
\hline & Precast habitat enhancement units & 1 \\
\hline & Seeded, textured or complex tiles or panels & 1 \\
\hline & Transplant target species & 1 \\
\hline \multirow{4}{*}{$\begin{array}{l}\text { Tidal river walls } \\
\text { (see SI Table 4) }\end{array}$} & Addition of natural material & 1 \\
\hline & Floating island habitats & 1 \\
\hline & Timber fenders \& ledges & 1 \\
\hline & Wall boxes & 2 \\
\hline \multirow[t]{2}{*}{ Floating pontoons } & Addition of synthetic material & 1 \\
\hline & Seeded, textured or complex tiles or panels & 3 \\
\hline
\end{tabular}

habitats, key references and associated costs (if known). It is important to note that the cost of interventions was not scaled up or standardised across all studies presented. We included as much consistent information from these studies as possible, but only used information derived from the authors' original interpretations.

\section{What structures are covered?}

We considered a range of coastal and estuarine structures: (1) Rock revetment, breakwaters and groynes include structures perpendicular and parallel to the shore composed of armour stones or concrete units, which are typically sloping structures that function to retain land, shelter a coastal area from incident waves or dissipate wave energy. (2) Vertical and sloping seawalls are solid, protective structures, including harbour walls and docks, designed to retain land and reflect wave energy. (3) Over-water structures include bridges and piers (and their supportive

reviewed only include projects with measurable ecological objectives published in grey and academic literature 
pilings). (4) Tidal river walls are typically vertical or sloping structures that provide flood defence and erosion mitigation where riverine freshwater meets the sea. (5) Vulnerable, degraded and culturally valuable structures include structures that are not permitted to be manipulated because of cultural or heritage value, or because of their state of deterioration. (6) Floating pontoons (or floating docks) are hollow structures used as walkways and for docking boats, most often within marinas. All the studies reviewed consisted of interventions made to existing structures or incorporated within structures during their construction. We do not describe nearshore or offshore artificial reefs as habitat for fisheries, as well as eco-engineering of the upper reaches of rivers because comprehensive reviews on these subjects exist (e.g., Nakamura 1985; Baine 2001; Palmer et al. 2005; Radspinner et al. 2010; Lokesha et al. 2013; Lima et al. 2019) and these habitats fall outside the remit of this paper.

\section{How to use this guide}

Caveat: We caution that the options outlined in this guide should be used responsibly; they should not be used to influence the consenting process for harmful coastal developments.

Whilst secondary management goals (e.g., enhance biodiversity, increase water filtration) for any eco-engineering design should be clearly defined at the outset, we appreciate that managers may not be aware of the range of potential interventions (see Evans et al. (2017) for a list of potential secondary benefits of designing multi-functional engineered structures suggested by a group of stakeholders). Consequently, we present a step-by-step approach that will direct the user to relevant information and help guide them through the range of eco-engineering options that are currently available.

Step 1. Refer to Fig. 2 which illustrates a series of questions that managers should consider in relation to incorporating eco-engineering into a planned development. The user should move through the questions sequentially, although some questions may not be applicable in every case.

Step 2. Refer to the appropriate section and table. Figure 2 directs users to the appropriate section (in-text) and table (Supplementary Information) containing information from previous studies for the particular structure type that they are working with. It is important to note that some enhancement designs may be applicable to structure types across multiple groups.

Step 3. Refer to Table 2 which details additional generic considerations that may be applicable.

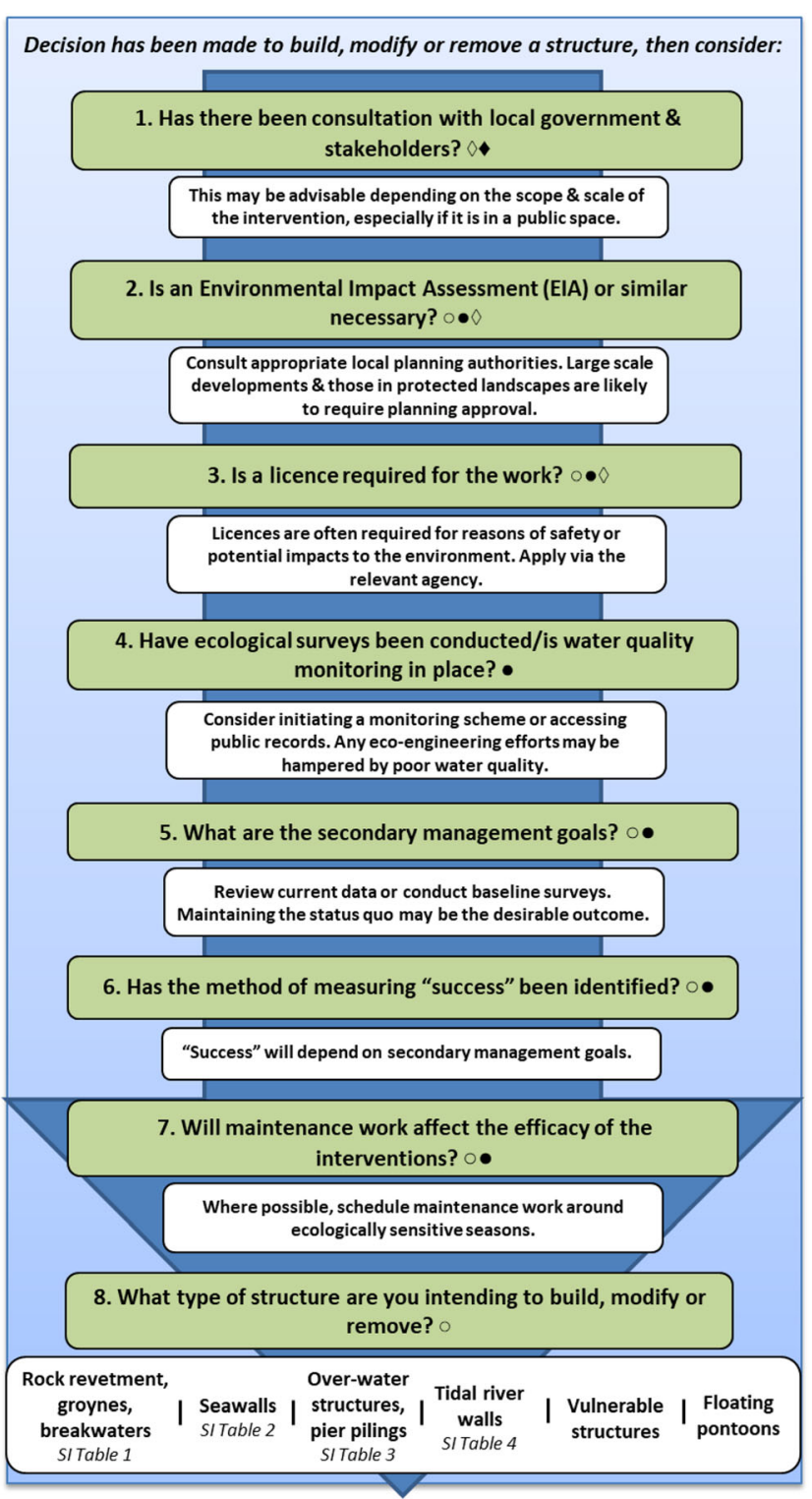

Fig. 2 Considerations for developers and managers relating to ecoengineering decisions for coastal and marine artificial structures. Question \#8 prompts the user to choose the structure type of interest and refer to the associated section (in-text) and table (Supplementary Information) for design details and examples. Symbols represent different consideration types: $\odot$ Engineering, $\bullet$ Environmental, $\diamond$ Governmental, Societal

\section{Eco-engineering of different artificial structures}

Much progress has been made in the field of eco-engineering, and a wide range of options is emerging, which are provided within this paper. We strongly caution, however, that many designs have only been trialled once, or only under certain environmental conditions or regions (i.e., temperate regions), and so it is unknown whether the same results would emerge under different environmental 
Table 2 Checklist for additional generic considerations that may be applicable to the chosen eco-engineering intervention

\begin{tabular}{|c|c|}
\hline Considerations & References \\
\hline \multicolumn{2}{|l|}{$\nabla$ Implementation } \\
\hline \multicolumn{2}{|l|}{ Implementation of design can be during construction or retrofitted } \\
\hline $\begin{array}{l}\text { - During construction: Designs may be covered by the licence for the construction work, be more } \\
\text { creative, less expensive \& implemented on a larger scale than if fitted retrospectively }\end{array}$ & Firth et al. 2014b; Sella \& Perkol-Finkel 2015 \\
\hline $\begin{array}{l}\text { - Retrofitting existing structures: Cost-effective options are available, such as affixing additional } \\
\text { material, drilling pits, grooves \& pools \& transplanting desirable habitats or species }\end{array}$ & $\begin{array}{l}\text { Browne \& Chapman 2011; Perkol-Finkel et al. } \\
\text { 2012; Evans et al. 2016; Strain et al. 2017b }\end{array}$ \\
\hline \multicolumn{2}{|c|}{$\checkmark$ Materials } \\
\hline \multicolumn{2}{|l|}{ Geological origin of material used can affect colonising communities, therefore try to: } \\
\hline - Use material local to the region & Burcharth \& Lamberti 2007; Green et al. 2012 \\
\hline - Use eco-friendly or natural material & ECOncrete Inc.; Dennis et al. 2017 \\
\hline - Use cement replacements (e.g., ground granulated blast-furnace slag) & McManus et al. 2017 \\
\hline \multicolumn{2}{|l|}{$\checkmark$ Placement } \\
\hline \multicolumn{2}{|l|}{ Performance of eco-engineering designs may be influenced by: } \\
\hline \multicolumn{2}{|l|}{ - Immersion gradient } \\
\hline $\begin{array}{l}\text { Subtidal \& lower intertidal: Placement of interventions here yields markedly } \\
\text { greater biodiversity as this area is immersed on every tidal cycle \& the } \\
\text { potential pool of colonising species is greater; however the risk of sand scour } \\
\text { is greater, which may result in loss of the intervention }\end{array}$ & Browne \& Chapman 2011; Firth et al. 2016a \\
\hline $\begin{array}{l}\text { Middle \& high intertidal: Placement of interventions here may help extend the } \\
\text { area of suitable habitat, which is normally compressed \& greatly reduced } \\
\text { compared to the intertidal zone in natural rocky shore }\end{array}$ & Perkol-Finkel \& Sella 2015 \\
\hline \multicolumn{2}{|l|}{ - Exposure gradient } \\
\hline Sheltered sites: Design may becoming inundated with sediment & Evans et al. 2016; Firth et al. 2016a \\
\hline Exposed sites: Design may be lost to currents \& waves & Francis et al. 2008; Browne \& Chapman 2014 \\
\hline \multicolumn{2}{|l|}{ - Aspect } \\
\hline \multirow{2}{*}{$\begin{array}{l}\text { Directionality (north vs. south in particular) determines the magnitude } \\
\text { of shading \& thermal stress a structure receives }\end{array}$} & Chapman \& Blockley 2009 \\
\hline & Chapman \& Underwood 2011 \\
\hline \multicolumn{2}{|l|}{ - Inclination } \\
\hline Substrate slope may determine the colonising community, as survivability & Francis \& Hoggart 2008; Dafforn et al. 2012 \\
\hline \multicolumn{2}{|l|}{ on horizontal vs. vertical substrate is species-specific \& thus might } \\
\hline \multicolumn{2}{|l|}{ influence success of invasive species } \\
\hline \multicolumn{2}{|l|}{$\sqrt{\text { Timing of installation }}$} \\
\hline \multicolumn{2}{|l|}{ of marine life \& subsequent community development vary throughout the year } \\
\hline \multicolumn{2}{|l|}{$\nabla$ Maintenance of structure } \\
\hline Maintenance can result in disturbance, often creating bare space where dense biological & Stachowicz et al. 1999; Airoldi \& Bulleri 2011 \\
\hline \multicolumn{2}{|l|}{ assemblages occurred previously, increasing the risk of colonisation by invasive species } \\
\hline \multicolumn{2}{|l|}{$\checkmark$ Uncontrollable factors } \\
\hline \multicolumn{2}{|l|}{ The precise effects of eco-engineering interventions are difficult to predict because coastal } \\
\hline \multicolumn{2}{|l|}{ \& marine systems are highly variable, with many uncontrollable conditions } \\
\hline \multicolumn{2}{|l|}{ - Local conditions: Consider the success of past designs in similar locations \& conditions } \\
\hline \multicolumn{2}{|l|}{ - Extreme weather events: Use information on weather trends in the region } \\
\hline \multicolumn{2}{|l|}{$\begin{array}{l}\text { - Obtaining permissions to install a design: Many structural design features of artificial } \\
\text { structures are non-negotiable because of their primary function \& cost restrictions }\end{array}$} \\
\hline
\end{tabular}

conditions. This is a major limitation in this field; we acknowledge that more evidence is needed before most ecoengineering designs can become routine practice (Evans et al. 2019). There are, however, examples showing that rigorous testing in a variety of different geographic and environmental settings can lead to large-scale implementation (see World Harbour Project 2018; ECOncrete Inc. 2019; Ecostructure 2019; Living Seawalls 2019). Thus, when choosing an eco-engineering intervention, it is vital to consider all physical (e.g., wave action, storm frequency, sediment loading, turbidity), chemical (e.g., salinity regime, nutrient supply, pollution loading) and biological factors (e.g., pool of potential colonising species, larval supply, proximity to point of introduction of invasive species). Moreover, it is crucial that developers and engineers engage with local ecologists, oceanographers and experts to discuss the feasibility of options so that valuable resources are not wasted, and the outcomes of ecoengineering installations maximised. In this light, any trials that failed to meet their ecological goals should be reported and considered when designs in new areas are being planned. 
Rock revetment, breakwaters and groynes made of armour stones or concrete units (supplementary information Table 1)

There are many options for eco-engineering these structures. Small-scale physical modifications involve drilling pits and rock pools (Firth et al. 2014; Evans et al. 2016; Hall et al. 2018). Large-scale physical interventions involve placement of precast habitat-enhancement units within the existing structure or during construction (Firth et al. 2014; Perkol-Finkel and Sella 2015; Sella and Perkol-Finkel 2015). Biological modifications include transplanting target species to the structure for habitat enhancement or conservation purposes (Perkol-Finkel et al. 2012). Hybrid methods consist of combining planted vegetation (e.g., saltmarsh cordgrass, mangrove trees) or reef-forming animals (e.g., oysters, coral) with built structures to mitigate erosion and rehabilitate coastal habitat (Hashim et al. 2010; Kamali et al. 2010; Bilkovic and Mitchell 2013).

\section{Vertical and sloping seawalls (supplementary information Table 2)}

Options for eco-engineering seawalls include drilling pits into pre-existing seawalls (Martins et al. 2010; Martins et al. 2016), manipulating wet mortar to create grooves and pits in new seawalls (Firth et al. 2014; Jackson 2015) and transplanting target species or species of conservation concern directly onto seawalls (Ng et al. 2015). Structural complexity can be added by attaching concrete panels to seawalls (Cordell et al. 2017; Perkol-Finkel et al. 2017; Strain et al. 2017b; World Harbour Project 2018), and water-retaining features can be created by retro-fitting precast concrete units on seawalls or replacing blocks with cavities during seawall construction (Chapman and Blockley 2009; Browne and Chapman 2014; Morris et al. 2018b; Hall et al. 2019).

\section{Over-water structures, such as bridges and piers, and their associated supporting pilings (supplementary information Table 3)}

Over-water structures and their associated foundational support structures may alter natural physical characteristics, such as hydrodynamics, sediment movement and light penetration in the immediate area (Smith and Mezich 1999; Shafer 2002; Dugan et al. 2011; Li et al. 2014). These physical modifications result in changes to ecosystem functioning, including fish migration behaviour (Ono and Simenstad 2014; Munsch et al. 2017) and seagrass survival (Blanton et al. 2002; Shafer 2002). To alleviate some of the negative effects associated with over-water structures, ecologists have experimented with light-penetrating materials (Shafer and Lundin 1999; Alexander 2012; Cordell et al. 2017) and artificial lighting
(Ono and Simenstad 2014). Ecological encasement jackets (Perkol-Finkel and Sella 2015) and synthetic free-hanging ropes (Paalvast et al. 2012) have been trialled on pier pilings, which had positive effects on biodiversity and local water quality through biofiltration, and without compromising the functional integrity of pilings.

\section{Tidal river walls and embankments (supplementary information Table 4)}

Tidal rivers and estuaries are among the most degraded and altered aquatic ecosystems in the world as many are located in urban areas (Malmqvist and Rundle 2002; Lotze et al. 2006), yet there has been a paucity of eco-engineering interventions attempted in these systems (but see Francis et al. 2008; Francis 2009; Hoggart and Francis 2014). Eco-engineering options for tidal river walls include attachment of timber fenders, wall modules and wire mesh to river walls. These can act as surface roughness elements, reducing water flow velocity and facilitating seed trapping and germination of vegetation (Steele 1999; Schanze et al. 2004; Hoggart and Francis 2014). The use of floating structures such as fish hotels is not a direct enhancement to an artificial structure, but such designs do facilitate recruitment of riparian vegetation and invertebrate species, as well as provide shelter and habitat for fish and haul-out sites for seals (Francis 2009; Yellin 2014).

\section{Vulnerable, degraded and culturally valuable artificial structures on which manipulations are not permitted}

Some artificial structures are degraded or have cultural or heritage value, which can make it challenging to obtain permissions for retrofitting eco-engineering interventions, especially interventions that involve drilling or attaching heavy materials. For example, Plymouth Breakwater, built between 1812 and 1841, is a $1.6 \mathrm{~km}$ long structure (Southward and Orton 1954; Hawkins et al. 1983) that is considered a historic monument (Knights et al. 2016) and that is not permitted to be manipulated. As the original structure has become undermined over the years, sacrificial concrete wave-breaker blocks (100 t) are systematically placed on the seaward side of the breakwater as an additional form of protection from wave action. These blocks may function similarly to boulders or rubble placed at the base of seawalls, in that they create additional habitat that supports species that do not live on the original structure itself (Chapman 2012, 2017; Firth et al. 2014; Liversage and Chapman 2018). Indeed, given their heritage status and aesthetic value of these kinds of structures, the best approach may be to do nothing.

To our knowledge, formal tests to enhance biodiversity on vulnerable structures have not been conducted, thus information contained within this section consists only of suggested interventions, and subsequently a guidance table on eco- 
engineering approaches has not been offered. Nevertheless, designs that have been trialled for other structures have the potential to be implemented in front of vulnerable structures for protection and provision of habitat for marine life. For example, if the goal is to provide a secondary form of protection for the structure and enhance the habitat potential, artificial boulder fields (Chapman 2012, 2017) or precast armouring units (Firth et al. 2014; Sella and Perkol-Finkel 2015; Reef Ball Foundation Inc. 2017; ARC Marine 2019) could be placed in front of the structure. There are companies designing commercial products to provide hard structures for erosion prevention and scour protection, whilst simultaneously enhancing biodiversity (Reef Ball Foundation Inc. 2017; ARC Marine 2019; ECOncrete Inc. 2019; Reef Design Lab 2019). It is imperative, however, to confirm that designs from these companies are rigorously tested, analysed and results published so that there is confidence in the delivery of ecological goals (e.g., see scientific testing done by ECOncrete Inc. 2019: Perkol-Finkel and Sella 2013; Perkol-Finkel and Sella 2015; Sella and Perkol-Finkel 2015; Perkol-Finkel et al. 2017).

\section{Floating pontoons}

Floating pontoons (also known as floating docks) are some of the most ubiquitous artificial structures in urban harbours. They are hollow structures made of materials such as concrete or fibreglass which are used as walkways and for berthing boats; they also inevitably provide substrate for biotic colonisation (Connell 2001; Toh et al. 2017). There are no natural analogues to pontoons, as they stay fixed in relation to the water level (they rise and fall with the tide so that the water depth below them varies), provide permanent shading and are typically located within enclosed environments (i.e., marinas; Hair and Bell 1992; Glasby and Connell 2001; Holloway and Connell 2002).

To date, descriptive work on pontoons has characterised the biological assemblages and has shown that these structures often support invasive species (Arenas et al. 2006a; Perkol-Finkel et al. 2008; Bishop et al. 2015; Toh et al. 2017), although few ecoengineering studies have been carried out on pontoons (but see Hair and Bell 1992; Stachowicz et al. 2002; Paalvast et al. 2012). This knowledge gap is reflected in the absence of a guidance table on eco-engineering approaches to pontoons in this paper. It is important to note that eco-engineering pontoons may be undesirable for marina operators because additional material on pontoons may affect buoyancy of pontoons and impede mooring of boats, and the associated organisms typically cover boat hulls and marina equipment (Connell 2001). In particular, invasive species (e.g., the carpet sea squirt, Didemnum vexillum) have been responsible for smothering pontoons, marina equipment and boat hulls and engines, costing marina managers and boat owners extra expenses in anti-fouling remedies (Coutts and
Forrest 2007; Piola et al. 2009). Thus, trials are urgently needed to test eco-engineering interventions that will support native biodiversity, thereby offsetting the success of invasive species.

\section{Concluding remarks}

As urbanisation along coastlines continues to increase, the pressure on coastal developers and local governments to invest in the design and management of defence structures to protect valuable infrastructure and preserve human lives will also increase. Stress from urbanisation will be exacerbated by rising sea level and more frequent and intense storms. Fortunately, there is impetus among stakeholders to work with natural processes where possible to preserve biodiversity and maintain valuable ecosystem services (Evans et al. 2017). Effective siting, planning and management of coastal developments to provide desirable ecological benefits to society and nature require a wide range of proof-of-concept options in a variety of environmental contexts. This paper has shown the range of eco-engineering options currently available, as well as provided a template upon which to build a practitioner-friendly user guide for environmentally sensitive development along urbanised coastlines.

The future of eco-engineering will necessarily include a wider ecosystem perspective; this will include combining "hard" and "soft" engineering (Bilkovic and Mitchell 2013; Temmerman et al. 2013; Hanley et al. 2014; Chee et al. 2017), and will involve a multifunctional approach to design structures that can synergistically support aquaculture, energy production, diverse biological communities and healthy ecosystems (Ten Voorde et al. 2009; Zanuttigh et al. 2015; Evans et al. 2017). Ecologists and engineers have developed a wide range of eco-engineering options and are beginning to develop frameworks and guidelines for end-users (Dafforn et al. 2015b; Dyson and Yocom 2015; Mayer-Pinto et al. 2017); but we caution that significant knowledge gaps remain regarding the applicability of these techniques outside the environmental scenarios in which they were trialled, and all designs carry with them an associated risk. As Bulleri and Chapman (2010) warned, it is not yet possible to provide a full "recipe book" of interventions from which engineers and developers may select the best approach with absolute confidence to possible outcomes (see also Evans et al. 2017). Thus, to inform sound eco-engineering practice, there is a need for wider testing of existing designs in different environmental settings, and to develop the predictive capability to forecast ecological outcomes (Airoldi et al. 2005; Hulme 2014; Evans 2016). Meticulous planning, informed decision-making and setting and measuring secondary management goals are vital in maximising the ecological and societal benefits of ecoengineering (Russell et al. 1983; Hawkins et al. 1992). Collaboration between developers, government bodies, ecologists and engineers is an essential prerequisite for 
maximising biodiversity gains and minimising ecological impacts of coastal development (Department for Communities and Local Government 2012).

The field of eco-engineering is still in its infancy; public and practitioner knowledge of eco-engineering may be limited due to lack of awareness (Strain et al. 2019). Ecologists should, therefore, communicate eco-engineering information to managers, decision-makers and the general public in a variety of different formats that will reach a diverse audience, such as integrating environmental education into school curricula (Strain et al. 2019) and children's media (e.g., Firth et al. 2016c), gaining corporate sponsorship (e.g., Living Seawalls 2019) and presenting at Soapbox Science events (Soapbox Science 2019). Eco-engineering information should be communicated without exaggeration or promise of desired results, with a foundational message that the best option for managing biodiversity and ecosystem functioning is to minimise interventions and work with nature whenever possible (e.g., sand banks, saltmarshes, mangroves; Airoldi et al. 2005; Hanley et al. 2014; Morris et al. 2018a).

Arguably more is learnt from failure than from success (see Firth et al. 2016b), and we advocate that reporting of failure is imperative. Reflecting the restricted distribution of eco-engineering trials grouped in a few geographical hotspots (i.e., Australia, Italy, Singapore, UK, USA; Firth et al. 2016a; Strain et al. 2017a) and limited types of structures studied (i.e., limited research on pontoons, offshore structures), we caution against unconsidered implementation of these recommendations without full consideration of the environmental context (see Table 2), overall management goals and desired target effects. With careful planning and consultation with the appropriate team of experts - local ecologists, engineers and societal stakeholders even heavily stressed coastal urban ecosystems can support greater biodiversity, enhancing functioning, thereby providing valuable ecosystem services for both nature and society.

Acknowledgements The authors would like to acknowledge all those who have contributed information and photographs to this work. The individual stages of research were supported by the European Commission DELOS project ("Environmental Design of Low Crested Coastal Defence Structures"); and the THESEUS project ("Innovative technologies for safer European coasts in a changing climate"). Supplementary funding was provided by the Esmée Fairbairn Foundation (URBANE; "Urban Research on Biodiversity on Artificial and Natural coastal Environments: enhancing biodiversity by sensitive design"); Marine Ecological Solutions Ltd.; KESS ("Knowledge Economy Skills Scholarships"; part-funded by the European Social Fund [ESF] through the European Union's Convergence Programme [West Wales and the Valleys] administered by the Welsh Government); the Ecostructure project (part-funded by the European Regional Development Fund [ERDF] through the Ireland Wales Cooperation Programme 2014-2020); the British Ecological Society [small grant: 5546-6590]; and the Royal Society [International Exchanges Grant: IE150435].
Open Access This article is licensed under a Creative Commons Attribution 4.0 International License, which permits use, sharing, adaptation, distribution and reproduction in any medium or format, as long as you give appropriate credit to the original author(s) and the source, provide a link to the Creative Commons licence, and indicate if changes were made. The images or other third party material in this article are included in the article's Creative Commons licence, unless indicated otherwise in a credit line to the material. If material is not included in the article's Creative Commons licence and your intended use is not permitted by statutory regulation or exceeds the permitted use, you will need to obtain permission directly from the copyright holder. To view a copy of this licence, visit http://creativecommons.org/licenses/by/4.0/.

\section{References}

Airoldi L, Beck MW (2007) Loss, status and trends for coastal marine habitats of Europe. Oceanogr Mar Biol Annu Rev 45:345-405

Airoldi L, Abbiati M, Beck MW, Hawkins SJ, Jonsson PR, Martin D, Moschella PS, Sundelöf A, Thompson RC, Åberg P (2005) An ecological perspective on the deployment and design of lowcrested and other hard coastal defence structures. Coast Eng 52: 1073-1087. https://doi.org/10.1016/j.coastaleng.2005.09.007

Alexander, C. (2012). Field Assessment and Simulation of Shading from Alternative Dock Construction Materials. Technical report to the Office of Ocean and Coastal Resource Management, National Oceanic and Atmospheric Administration. Final Report, 18

ARC Marine (2019). http://www.arcmarine.co.uk/. Accessed 10 Nov 2017

Arenas F, Bishop JDD, Carlton JT, Dyrynda PJ, Farnham WF, Gonzalez DJ, Jacobs MW, Lambert C, Lambert G, Nielsen SE, Pederson JA, Porter JS, Ward S, Wood CA (2006a) Alien species and other notable records from a rapid assessment survey of marinas on the south coast of England. J Mar Biol Assoc UK 86:1329-1337. https://doi. org/10.1017/S0025315406014354

Arenas F, Sánchez I, Hawkins SJ, Jenkins SR (2006b) The invasibility of marine algal assemblages: role of functional diversity and identity. Ecology. 87:2851-2861. https://doi.org/10.1890/0012-9658(2006) 87[2851:TIOMAA]2.0.CO;2

Arnold CL Jr, Gibbons CJ (1996) Impervious surface coverage: the emergence of a key environmental indicator. J Am Plan Assoc 62:243258. https://doi.org/10.1080/01944369608975688

Baine M (2001) Artificial reefs: a review of their design, application, management and performance. Ocean Coast Manag 44:241-259. https://doi.org/10.1016/S0964-5691(01)00048-5

Barnes KB, Morgan J, Roberge M (2001) Impervious surfaces and the quality of natural and built environments. Department of Geography and Environmental Planning, Towson University, Baltimore

Bilkovic DM, Mitchell MM (2013) Ecological tradeoffs of stabilized salt marshes as a shoreline protection strategy: effects of artificial structures on macrobenthic assemblages. Ecol Eng 61:469-481. https:// doi.org/10.1016/j.ecoleng.2013.10.011

Bishop JD, Wood CA, Lévêque L, Yunnie AL, Viard F (2015) Repeated rapid assessment surveys reveal contrasting trends in occupancy of marinas by non-indigenous species on opposite sides of the western English Channel. Mar Pollut Bull 95:699-706. https://doi.org/10. 1016/j.marpolbul.2014.11.043

Bishop MJ, Mayer-Pinto M, Airoldi L, Firth LB, Morris RL, Loke LH, Hawkins SJ, Naylor LA, Coleman RA, Chee SY, Dafforn KA (2017) Effects of ocean sprawl on ecological connectivity: impacts and solutions. J Exp Mar Biol Ecol 492:7-30. https://doi.org/10. 1016/j.jembe.2017.01.021 
Blanton S, Thom R, Borde A, Diefenderfer H, Southard J (2002) Evaluation of methods to increase light under ferry terminals. Report prepared for Washington State Department of Transportation https://doi.org/10.2172/15001597

Browne MA, Chapman MG (2014) Mitigating against the loss of species by adding artificial intertidal pools to existing seawalls. Mar Ecol Prog Ser 497:119-129. https://doi.org/10.3354/meps10596

Bulleri F, Chapman M (2004) Intertidal assemblages on artificial and natural habitats in marinas on the north-west coast of Italy. Mar Biol 145:381-391

Bulleri F, Chapman MG (2010) The introduction of coastal infrastructure as a driver of change in marine environments. J Appl Ecol 47:26-35. https://doi.org/10.1111/j.1365-2664.2009.01751.x

Chapman MG (2012) Restoring intertidal boulder-fields as habitat for "specialist" and "generalist" animals. Restor Ecol 20:277-285. https://doi.org/10.1111/j.1526-100X.2011.00789.x

Chapman MG (2017) Intertidal boulder-fields: a much neglected, but ecologically important, intertidal habitat. In: Hawkins SJ, Evans AJ, Dale AC, Firth LB, Hughes DJ, Smith IP (eds) Oceanography and Marine Biology: an Annual Review

Chapman MG, Blockley DJ (2009) Engineering novel habitats on urban infrastructure to increase intertidal biodiversity. Oecologia. 161: 625-635. https://doi.org/10.1007/s00442-009-1393-y

Chapman MG, Underwood AJ (2011) Evaluation of ecological engineering of "armoured" shorelines to improve their value as habitat. J Exp Mar Biol Ecol 400:302-313. https://doi.org/10.1016/j.jembe.2011. 02.025

Chee SY, Othman AG, Sim YK, Adam ANM, Firth LB (2017) Land reclamation and artificial islands: walking the tightrope between development and conservation. Glob Ecol Conserv 12:80-95. https://doi.org/10.1016/j.gecco.2017.08.005

Colwell RK (2009) Biodiversity: concepts, patterns, and measurement. In: Levin SA (ed) The Princeton guide to ecology. Princeton University Press, Princeton, pp 257-263

Connell SD (2001) Urban structures as marine habitats: an experimental comparison of the composition and abundance of subtidal epibiota among pilings, pontoons and rocky reefs. Mar Environ Res 52:115 125

Coombes MA, Naylor LA, Viles HA, Thompson RC (2013) Bioprotection and disturbance: seaweed, microclimatic stability and conditions for mechanical weathering in the intertidal zone. Geomorphology. 202:4-14. https://doi.org/10.1016/j.geomorph. 2012.09.014

Coombes MA, La Marca EC, Naylor LA, Thompson RC (2015) Getting into the groove: opportunities to enhance the ecological value of hard coastal infrastructure using fine-scale surface textures. Ecol Eng 77:314-323. https://doi.org/10.1016/j.ecoleng.2015.01.032

Cordell JR, Toft JD, Munsch S, Goff M (2017) Benches, beaches, and bumps: how habitat monitoring and experimental science can inform urban seawall design. Living shorelines: the science and management of nature-based coastal protection. CRC press, Boca Raton, Florida

Coutts AD, Forrest BM (2007) Development and application of tools for incursion response: lessons learned from the management of the fouling pest Didemnum vexillum. J Exp Mar Biol Ecol 342:154 162. https://doi.org/10.1016/j.jembe.2006.10.042

Dafforn KA, Johnston EL, Glasby TM (2009) Shallow moving structures promote marine invader dominance. Biofouling. 25:277-287. https://doi.org/10.1080/08927010802710618

Dafforn KA, Glasby TM, Johnston EL (2012) Comparing the invasibility of experimental "reefs" with field observations of natural reefs and artificial structures. PLoS One 7:e38124. https://doi.org/10.1371/ journal.pone. 0038124

Dafforn KA, Mayer-Pinto M, Morris RL, Waltham NJ (2015a) Application of management tools to integrate ecological principles with the design of marine infrastructure. J Environ Manag 158:6173. https://doi.org/10.1016/j.jenvman.2015.05.001

Dafforn KA, Glasby TM, Airoldi L, Rivero NK, Mayer-Pinto M, Johnston EL (2015b) Marine urbanization: an ecological framework for designing multifunctional artificial structures. Front Ecol Environ 13:82-90. https://doi.org/10.1890/140050

Del Río L, Gracia FJ, Benavente J (2013) Shoreline change patterns in sandy coasts. A case study in SW Spain. Geomorphology 196:252266. https://doi.org/10.1016/j.geomorph.2012.07.027

Department for Communities and Local Government (2012) National Planning Policy Framework, London

Duarte CM, Pitt KA, Lucas CH, Purcell JE, Uye S, Robinson K, Brotz L, Decker MB, Sutherland KR, Malej A, Madin L, Mianzan H, Gili JM, Fuentes V, Atienza D, Pagés F, Breitburg D, Malek J, Graham WM, Condon RH (2012) Is global ocean sprawl a cause of jellyfish blooms? Front Ecol Environ 11:91-97. https://doi.org/10.1890/ 110246

Dugan JE, Hubbard DM, Rodil IF, Revell DL, Schroeter S (2008) Ecological effects of coastal armoring on sandy beaches. Mar Ecol 29:160-170. https://doi.org/10.1111/j.1439-0485.2008.00231.x

Dugan J, Airoldi L, Chapman M, Walker S, Schlacher T (2011) Estuarine and coastal structures: environmental effects, a focus on shore and nearshore structures. Treatise Estuar Coast Sci 8:17-41. https://doi. org/10.1016/B978-0-12-374711-2.00802-0

Dyson K, Yocom K (2015) Ecological design for urban waterfronts. Urban Ecosyst 18:189-208. https://doi.org/10.1007/s11252-0140385-9

ECOncrete Inc. (2019). http://www.econcretetech.com/. Accessed 15 June 2019

Ecostructure (2019). http://www.ecostructureproject.eu/. Accessed 10 May 2019

Evans AJ (2016) Artificial coastal defence structures as surrogate habitats for natural rocky shores: giving nature a helping hand. Aberystwyth University, Aberystwyth

Evans AJ, Firth LB, Hawkins SJ, Morris ES, Goudge H, Moore PJ (2016) Drill-cored rock pools: an effective method of ecological enhancement on artificial structures. Mar Freshw Res 67:123-130. https:// doi.org/10.1071/MF14244

Evans AJ, Garrod B, Firth LB, Hawkins SJ, Morris-Webb ES, Goudge H, Moore PJ (2017) Stakeholder priorities for multi-functional coastal defence developments and steps to effective implementation. Mar Policy 75:143-155. https://doi.org/10.1016/j.marpol.2016.10.006

Evans AJ, Firth LB, Hawkins SJ, Hall AE, Ironside JE, Thompson RC, Moore PJ (2019) From ocean sprawl to blue-green infrastructure-a UK perspective on an issue of global significance. Environ Sci Pol 91:60-69

Everard, M (2017) Ecosystem Services: Key Issues, London and New York, Taylor \& Francis.

Firth LB, Thompson RC, Bohn K, Abbiati M, Airoldi L, Bouma TJ, Bozzeda F, Ceccherelli VU, Colangelo MA, Evans A, Ferrario F, Hanley ME, Hinz H, Hoggart SPG, Jackson JE, Moore PJ, Morgan EH, Perkol-Finkel S, Skov MW, Strain EM, Belzen JV, Hawkins SJ (2014) Between a rock and a hard place: environmental and engineering considerations when designing coastal defence structures. Coast Eng 87:122-135. https://doi.org/10.1016/j.coastaleng.2013. 10.015

Firth LB, Knights AM, Bridger D, Evans AJ, Mieszkowska N, Hawkins SJ, Moore PJ, O'Connor NE, Sheehan EV, Thompson RC (2016a) Ocean sprawl: challenges and opportunities for biodiversity management in a changing world. Oceanogr Mar Biol Annu Rev 54: 189-262. https://doi.org/10.1201/9781315368597

Firth LB, Browne KA, Knights AM, Hawkins SJ, Nash R (2016b) Ecoengineered rock pools: a concrete solution to biodiversity loss and urban sprawl in the marine environment. Environ Res Lett 11: 094015. https://doi.org/10.1088/1748-9326/11/9/094015 
Firth LB, Evans A, Knights A, Nash R, Browne K, Moore P, MorrisWebb E, Goudge H, Hawkins S (2016c) Could this be a concrete solution to biodiversity loss? Environmental Science Journal for Teens. www.ScienceJournalForKids.org

Francis RA (2009) Perspectives on the potential for reconciliation ecology in urban riverscapes. CAB Rev: Perspect Agric Vet Sci Nutr Nat Resour 4:1-20. https://doi.org/10.1079/PAVSNNR20094073

Francis RA, Hoggart SP, Gurnell AM, Coode C (2008) Meeting the challenges of urban river habitat restoration: developing a methodology for the river Thames through Central London. Area. 40:435445

French PW (2006) Managed realignment-the developing story of a comparatively new approach to soft engineering. Estuar Coast Shelf Sci 67:409-423. https://doi.org/10.1016/j.ecss.2005.11.035

Geist J, Hawkins SJ (2016) Habitat recovery and restoration in aquatic ecosystems: current progress and future challenges. Aquat Conserv Mar Freshwat Ecosyst 26:942-962. https://doi.org/10.1002/aqc. 2702

Glasby TM, Connell SD (2001) Orientation and position of substrata have large effects on epibiotic assemblages. Mar Ecol Prog Ser 214:127-135

Glasby TM, Connell SD, Holloway MG, Hewitt CL (2007) Nonindigenous biota on artificial structures: could habitat creation facilitate biological invasions? Mar Biol 151:887-895. https://doi. org/10.1007/s00227-006-0552-5

Govarets A, Lauwaert B (2009) Assessment of the impact of coastal defence structures. Biodiversity series: OSPAR Commission

Hair C, Bell J (1992) Effects of enhancing pontoons on abundance of fish: initial experiments in estuaries. Bull Mar Sci 51:30-36

Hall A, Herbert RH, Britton JR, Hull S (2018) Ecological enhancement techniques to improve habitat heterogeneity on coastal defence structures. Estuar Coast Shelf Sci. https://doi.org/10.1016/j.ecss. 2018.05.025

Hall AE, Herbert RJH, Britton RJ, Boyd I, George N (2019) Shelving the coast with Vertipools: retrofitting artificial rock pools on coastal structures as mitigation for coastal squeeze. Front Mar Sci 6:456. https://doi.org/10.3389/fmars.2019.00456

Halpern BS, Walbridge S, Selkoe KA, Kappel CV, Micheli F, D'agrosa C, Bruno JF, Casey KS, Ebert C, Fox HE, Fujita R, Heinemann D, Lenihan HS, Madin EMP, Perry MT, Selig ER, Spalding M, Steneck R, Watson R (2008) A global map of human impact on marine ecosystems. Science. 319:948-952. https://doi.org/10.1126/ science. 1149345

Hanley ME, Hoggart SPG, Simmonds DJ, Bichot A, Colangelo MA, Bozzeda F, Heurtefeux H, Ondiviela B, Ostrowski R, Recio M, Trude R, Zawadzka-Kahlau E, Thompson RC (2014) Shifting sands? Coastal protection by sand banks, beaches and dunes. Coast Eng 87:136-146. https://doi.org/10.1016/j.coastaleng.2013. 10.020

Hashim R, Kamali B, Tamin NM, Zakaria R (2010) An integrated approach to coastal rehabilitation: mangrove restoration in Sungai haji Dorani. Malaysia Estuar Coast Shelf Sci 86:118-124. https://doi. org/10.1016/j.ecss.2009.10.021

Hawkins SJ, Southward AJ, Barrett RL (1983) Population structure of Patella vulgata L. during succession on rocky shores in southwest England. Oceanologica Acta, Special Issue

Hawkins SJ, Allen JR, Russell G, White KN, Conlan K, Hendry K, Jones HD (1992) Restoring and managing disused docks in inner city areas. In: Thayer G (ed) Restoring the Nation's Marine Environment. . pp 473-542

Heery EC, Bishop MJ, Critchley LP, Bugnot AB, Airoldi L, Mayer-Pinto M, Sheehan EV, Coleman RA, Loke LH, Johnston EL (2017) Identifying the consequences of ocean sprawl for sedimentary habitats. J Ex Mar Biol Ecol 492:31-48

Hobbs RJ, Arico S, Aronson J, Baron JS, Bridgewater P, Cramer VA, Epstein PR, Ewel JJ, Klink CA, Lugo AE, Norton D, Ojima D,
Richardson DM, Sanderson EW, Valladares F, Vilà M, Zamora R, Zobel M (2006) Novel ecosystems: theoretical and management aspects of the new ecological world order. Glob Ecol Biogeogr 15: 1-7. https://doi.org/10.1111/j.1466-822x.2006.00212.x

Hoggart SPG, Francis RA (2014) Use of coir rolls for habitat enhancement of urban river walls. Fundam Appl Limnol 185:19-30. https:// doi.org/10.1127/fal/2014/0571

Hoggart SPG, Hanley ME, Parker DJ, Simmonds DJ, Bilton DT, Filipova-Marinova M, Franklin EL, Kotsev I, Penning-Rowsell EC, Rundle SD (2014) The consequences of doing nothing: the effects of seawater flooding on coastal zones. Coast Eng 87:169182. https://doi.org/10.1016/j.coastaleng.2013.12.001

Holloway M, Connell S (2002) Why do floating structures create novel habitats for subtidal epibiota? Mar Ecol Prog Ser 235:43-52

Hulme PE (2014) EDITORIAL: bridging the knowing-doing gap: knowwho, know-what, know-why, know-how and know-when. J Appl Ecol 51:1131-1136. https://doi.org/10.1111/1365-2664.12321

Jackson JE (2015) The influence of engineering design considerations on species recruitment and succession on coastal defence structures. Plymouth University, Plymouth

Kamali B, Hashim R, Akib S (2010) Efficiency of an integrated habitat stabilisation approach to coastal erosion management. Int J Phys Sci 5:1401-1405

Knights AM, Piet GJ, Jongbloed RH, Tamis JE, White L, Akoglu E, Boicenco L, Churilova T, Kryvenko O, Fleming-Lehtinen V, Leppanen JM, Galil BS, Goodsir F, Goren M, Margonski P, Moncheva S, Oguz T, Papadopoulou KN, Setala O, Smith CJ, Stefanova K, Timofte F, Robinson LA (2015) An exposure-effect approach for evaluating ecosystem-wide risks from human activities. ICES J Mar Sci 72:1105-1115. https://doi.org/10.1093/icesjms/ fsu 245

Knights AM, Firth LB, Thompson RC, Yunnie AL, Hiscock K, Hawkins SJ (2016) Plymouth - a world harbour through the ages. Reg Stud Mar Sci 8:297-307. https://doi.org/10.1016/j.rsma.2016.02.002

Knott NA, Underwood AJ, Chapman MG, Glasby TM (2004) Epibiota on vertical and on horizontal surfaces on natural reefs and on artificial structures. J Mar Biol Assoc UK 84:1117-1130. https://doi.org/ 10.1017/S0025315404010550h

Krauss J, Bommarco R, Guardiola M, Heikkinen RK, Helm A, Kuussaari M, Lindborg R, Öckinger E, Pärtel M, Pino J (2010) Habitat fragmentation causes immediate and time-delayed biodiversity loss at different trophic levels. Ecol Lett 13:597-605

Lai S, Loke LH, Bouma TJ, Todd PA (2018) Biodiversity surveys and stable isotope analyses reveal key differences in intertidal assemblages between tropical seawalls and rocky shores. Mar Ecol Prog Ser 587:41-53. https://doi.org/10.3354/meps12409

Li P, Li G, Qiao L, Chen X, Shi J, Gao F, Wang N, Yue S (2014) Modeling the tidal dynamic changes induced by the bridge in Jiaozhou Bay, Qingdao. China Cont Shelf Res 84:43-53. https://doi.org/10.1016/j. csr.2014.05.006

Lima JS, Zalmon IR, Love M (2019) Overview and trends of ecological and socioeconomic research on artificial reefs. Mar Environ Res. https://doi.org/10.1016/j.marenvres.2019.01.010

Liversage K, Chapman M (2018) Coastal ecological engineering and habitat restoration: incorporating biologically diverse boulder habitat. Mar Ecol Prog Ser 593:173-185. https://doi.org/10.3354/ meps 12541

Living Seawalls (2019). https:/www.volvocars.com/au/why-volvo/ discover/living-seawall. Accessed 09 May 2019

Lokesha N, Sundar V, Sannasiraj S (2013) Artificial reefs: a review. Int J Ocean Clim Syst 4:117-124

Lotze HK, Lenihan HS, Bourque BJ, Bradbury RH, Cooke RG, Kay MC, Kidwell SM, Kirby MX, Peterson CH, Jackson JB (2006) Depletion, degradation, and recovery potential of estuaries and coastal seas. Science. 312:1806-1809. https://doi.org/10.1126/ science. 1128035 
Ma Z, Melville DS, Liu J, Chen Y, Yang H, Ren W, Zhang Z, Piersma T, Li B (2014) Rethinking China's new great wall. Science. 346:912914. https://doi.org/10.1126/science. 1257258

Macdonald E, King EG (2018) Novel ecosystems: a bridging concept for the consilience of cultural landscape conservation and ecological restoration. Landsc Urban Plan 177:148-159

Malmqvist B, Rundle S (2002) Threats to the running water ecosystems of the world. Environ Conserv 29:134-153. https://doi.org/10.1017/ S0376892902000097

Martins GM, Thompson RC, Neto AI, Hawkins SJ, Jenkins SR (2010) Enhancing stocks of the exploited limpet Patella candei d'Orbigny via modifications in coastal engineering. Biol Conserv 143:203211. https://doi.org/10.1016/j.biocon.2009.10.004

Martins GM, Jenkins SR, Neto AI, Hawkins SJ, Thompson RC (2016) Long-term modifications of coastal defences enhance marine biodiversity. Environ Conserv 43:109-116. https://doi.org/10.1017/ S0376892915000284

Masselink G, Hanley ME, Halwyn AC, Blake W, Kingston K, Newton T, Williams M (2017) Evaluation of salt marsh restoration by means of self-regulating tidal gate - Avon estuary, South Devon. UK Ecol Eng 106:174-190. https://doi.org/10.1016/j.ecoleng.2017.05.038

Mayer-Pinto M, Johnston EL, Bugnot AB, Glasby TM, Airoldi L, Mitchell A, Dafforn KA (2017) Building 'blue': an ecoengineering framework for foreshore developments. J Environ Manag 189:109-114. https://doi.org/10.1016/j.jenvman.2016.12. 039

Mayer-Pinto M, Cole V, Johnston EL, Bugnot A, Hurst H, Airoldi L, Glasby T, Dafforn K (2018a) Functional and structural responses to marine urbanisation. Environ Res Lett 13(1):014009. https:// doi.org/10.1088/1748-9326/aa98a5

Mayer-Pinto M, Dafforn K, Bugnot A, Glasby T, Johnston E (2018b) Artificial structures alter kelp functioning across an urbanised estuary. Mar Environ Res

McGranahan G, Balk D, Anderson B (2007) The rising tide: assessing the risks of climate change and human settlements in low elevation coastal zones. Environ Urban 19:17-37. https://doi.org/10.1177/ 0956247807076960

Millennium Ecosystem Assessment (2005) Ecosystems and Human Well-being: Synthesis, Washington, DC, Island Press.

Milton SJ (2003) 'Emerging ecosystems' - a washing-stone for ecologists, economists and sociologists? S Afr J Sci 99:404-406

Mitsch WJ, Jorgensen SE (1989) Ecotechnology - an introduction to ecological engineering. Wiley, New York

Morris RL, Konlechner TM, Ghisalberti M, Swearer SE (2018a) From grey to green: efficacy of eco-engineering solutions for nature-based coastal defence. Glob Chang Biol. https://doi.org/10.1111/gcb. 14063

Morris RL, Martinez AS, Firth LB, Coleman RA (2018b) Can transplanting enhance mobile marine invertebrates in ecologically engineered rock pools? Mar Environ Res 141:119-127

Morse NB, Pellissier PA, Cianciola EN, Brereton RL, Sullivan MM, Shonka NK, Wheeler TB, McDowell WH (2014) Novel ecosystems in the Anthropocene: a revision of the novel ecosystem concept for pragmatic applications. Ecol Soc 19. https://doi.org/10.5751/ES06192-190212

Moschella PS, Abbiati M, Åberg P, Airoldi L, Anderson JM, Bacchiocchi F, Bulleri F, Dinesen GE, Frost M, Gacia E (2005) Low-crested coastal defence structures as artificial habitats for marine life: using ecological criteria in design. Coast Eng 52:1053-1071. https://doi. org/10.1016/j.coastaleng.2005.09.014

Munsch SH, Cordell JR, Toft JD (2017) Effects of shoreline armouring and overwater structures on coastal and estuarine fish: opportunities for habitat improvement. J Appl Ecol 54:1373-1384. https://doi.org/ $10.1111 / 1365-2664.12906$

Nakamura M (1985) Evolution of artificial fishing reef concepts in Japan. Bull Mar Sci 37:271-278
Naylor LA, Kippen H, Coombes MA, Horton B, MacArthur M, Jackson N (2017) Greening the Grey: a framework for integrated green grey infrastructure (IGGI). University of Glasgow, Glasgow

Ng CSL, Lim SC, Ong JY, Teo LMS, Chou LM, Chua KE, Tan KS (2015) Enhancing the biodiversity of coastal defence structures: transplantation of nursery-reared reef biota onto intertidal seawalls. Ecol Eng 82:480-486. https://doi.org/10.1016/j.ecoleng.2015.05. 016

Nordstrom KF (2014) Living with shore protection structures: a review. Estuar Coast Shelf Sci 150:11-23

Odum HT (1962) Man in the ecosystem. Conn Storrs Agric Exp Stat Bull 652:75-75

Odum HT, Odum B (2003) Concepts and methods of ecological engineering. Ecol Eng 20:339-361. https://doi.org/10.1016/j.ecoleng. 2003.08.008

Ono K, Simenstad CA (2014) Reducing the effect of overwater structures on migrating juvenile salmon: an experiment with light. Ecol Eng 71:180-189. https://doi.org/10.1016/j.ecoleng.2014.07.010

Paalvast P, van Wesenbeeck BK, van der Velde G, de Vries MB (2012) Pole and pontoon hulas: an effective way of ecological engineering to increase productivity and biodiversity in the hard-substrate environment of the port of Rotterdam. Ecol Eng 44:199-209. https://doi. org/10.1016/j.ecoleng.2012.04.002

Palmer MA, Bernhardt ES, Allan JD, Lake PS, Alexander G, Brooks S, Carr J, Clayton S, Dahm CN, Follstad Shah J, Galat DL, Loss SG, Goodwin P, Hart DD, Hassett B, Jenkinson R, Kondolf GM, Lave R, Meyer JL, O'Donnell TK, Pagano L, Sudduth E (2005) Standards for ecologically successful river restoration. J Appl Ecol 42:208 217. https://doi.org/10.1111/j.1365-2664.2005.01004.x

Perkol-Finkel S, Sella I (2013) Ecologically active concrete for coastal and marine infrastructure: innovative matrices and designs. ICE Publishing, Edinburgh

Perkol-Finkel S, Sella I (2015) Harnessing urban coastal infrastructure for ecological enhancement vol 168. Thomas Telford Ltd https://doi. org/10.1680/jmaen.15.00017

Perkol-Finkel S, Zilman G, Sella I, Miloh T, Benayahu Y (2008) Floating and fixed artificial habitats: spatial and temporal patterns of benthic communities in a coral reef environment. Estuar Coast Shelf Sci 77: 491-500. https://doi.org/10.1016/j.ecss.2007.10.005

Perkol-Finkel S, Ferrario F, Nicotera V, Airoldi L (2012) Conservation challenges in urban seascapes: promoting the growth of threatened species on coastal infrastructures. J Appl Ecol 49:1457-1466. https://doi.org/10.1111/j.1365-2664.2012.02204.x

Perkol-Finkel S, Hadary T, Rella A, Shirazi R, Sella I (2017) Seascape architecture-incorporating ecological considerations in design of coastal and marine infrastructure. Ecol Eng 120:645-654. https:// doi.org/10.1016/j.ecoleng.2017.06.051

Piola RF, Dafforn KA, Johnston EL (2009) The influence of antifouling practices on marine invasions. Biofouling. 25:633-644. https://doi. org/10.1080/08927010903063065

Polk MA, Eulie DO (2018) Effectiveness of living shorelines as an Erosion control method in North Carolina. Estuaries Coast 41: 2212-2222. https://doi.org/10.1007/s12237-018-0439-y

Popkin G, (2015) Fourteen percent of U.S. coastline is covered in concrete. Science [Online]. Available: https://www.sciencemag.org/ news/2015/08/fourteen-percent-us-coastline-covered-concrete. Accessed 19 December 2019

Radspinner RR, Diplas P, Lightbody AF, Sotiropoulos F (2010) River training and ecological enhancement potential using in-stream structures. J Hydraul Eng 136:967-980. https://doi.org/10.1061/(ASCE) HY.1943-7900.0000260

Reef Ball Foundation Inc (2017). http://www.reefball.org. Accessed 05 October 2019

Reef Design Lab (2019). www.reefdesignlab.com. Accessed 9 May 2017

Risinger JD (2012) Biologically dominated engineered coastal breakwaters. Louisiana State University, Baton Rouge 
Russell G, Hawkins SJ, Evans LC, Jones HD, Holmes GD (1983) Restoration of a disused dock basin as a habitat for marine benthos and fish. J Appl Ecol 20:43-58

Schanze J, Olfert A, Tourbier JT, Gersdorf I, Schwager T (2004) Existing Urban River rehabilitation schemes. Final report of WP2 from urban river basin enhancement methods, funded by the European Commission

Sella I, Perkol-Finkel S (2015) Blue is the new green - ecological enhancement of concrete based coastal and marine infrastructure. Ecol Eng 84:260-272. https://doi.org/10.1016/j.ecoleng.2015.09.016

Shafer DJ (2002) Recommendations to minimize potential impacts to seagrasses from single-family residential dock structures in the Pacific northwest. US Army Corps of Engineers, Seattle

Shafer DJ, Lundin J (1999) Design and construction of docks to minimize Seagrass impacts. DTIC Document,

Small C, Nicholls RJ (2003) A global analysis of human settlement in coastal zones. J Coast Res:584-599

Smith K, Mezich R (1999) Comprehensive assessment of the effects of single family docks on seagrass in Palm Beach County, Florida. Office of Environmental Services, Tallahassee

SoapBox Science (2019). http://soapboxscience.org/. Accessed 16 Aug 2019

Southward AJ, Orton JH (1954) The effects of wave-action on the distribution and numbers of the commoner plants and animals living on the Plymouth breakwater. J Mar Biol Assoc UK 33:1-19

Stachowicz JJ, Whitlatch RB, Osman RW (1999) Species diversity and invasion resistance in a marine ecosystem. Science. 286:1577-1579. https://doi.org/10.1126/science.286.5444.1577

Stachowicz JJ, Fried H, Osman RW, Whitlatch RB (2002) Biodiversity, invasion resistance, and marine ecosystem function: reconciling pattern and process. Ecology. 83:2575-2590. https://doi.org/10.1890/ 0012-9658(2002)083[2575:BIRAME]2.0.CO;2

Steele J (1999) Deptford Creek surviving regeneration. Deptford Forum Pub., Deptford Forum Publishing, London

Stive MJF, de Schipper MA, Luijendijk AP, Aarninkhof SGJ, van GelderMaas C, van Thiel de Vries JSM, de Vries S, Henriquez M, Marx S, Ranasinghe R (2013) A new alternative to saving our beaches from sea-level rise: the sand engine. J Coast Res 29:1001-1008. https:// doi.org/10.2112/JCOASTRES-D-13-00070.1

Strain EM, Olabarria C, Mayer-Pinto M, Cumbo V, Morris RL, Bugnot AB, Dafforn KA, Heery E, Firth LB, Brooks P, Bishop MJ (2017a) Eco-engineering urban infrastructure for marine and coastal biodiversity: which interventions have the greatest ecological benefit? J Appl Ecol 55:426-441. https://doi.org/10.1111/1365-2664.12961

Strain EMA, Morris RL, Coleman RA, Figueira WF, Steinberg PD, Johnston EL, Bishop MJ (2017b) Increasing microhabitat complexity on seawalls can reduce fish predation on native oysters. Ecol Eng 120:637-644. https://doi.org/10.1016/j.ecoleng.2017.05.030

Strain E, Alexander K, Kienker S, Morris R, Jarvis R, Coleman R, Bollard B, Firth L, Knights A, Grabowski J (2019) Urban blue: a global analysis of the factors shaping people's perceptions of the marine environment and ecological engineering in harbours. Sci Total Environ 658:1293-1305. https://doi.org/10.1016/j.scitotenv. 2018.12.285

Sutton-Grier AE, Wowk K, Bamford H (2015) Future of our coasts: the potential for natural and hybrid infrastructure to enhance the resilience of our coastal communities, economies and ecosystems. Environ Sci Pol 51:137-148. https://doi.org/10.1016/j.envsci.2015. 04.006

Temmerman S, Meire P, Bouma TJ, Herman PMJ, Ysebaert T, De Vriend HJ (2013) Ecosystem-based coastal defence in the face of global change. Nature. 504:79-83. https://doi.org/10.1038/nature12859

Ten Voorde M, do Carmo JA, Neves M (2009) Designing a preliminary multifunctional artificial reef to protect the Portuguese coast. J Coast Res:69-79. https://doi.org/10.2112/07-0827

Tessler Z, Vörösmarty CJ, Grossberg M, Gladkova I, Aizenman H, Syvitski J, Foufoula-Georgiou E (2015) Profiling risk and sustainability in coastal deltas of the world. Science. 349:638-643. https:// doi.org/10.1126/science.aab3574

Todd PA, Heery EC, Loke LH, Thurstan RH, Kotze DJ, Swan C (2019) Towards an urban marine ecology: characterizing the drivers, patterns and processes of marine ecosystems in coastal cities. Oikos. https://doi.org/10.1111/oik.05946

Toh KB, Ng CSL, Wu B, Toh TC, Cheo PR, Tun K, Chou LM (2017) Spatial variability of epibiotic assemblages on marina pontoons in Singapore. Urban Ecosyst 20:183-197. https://doi.org/10.1007/ s11252-016-0589-2

Vitousek PM, Mooney HA, Lubchenco J, Melillo JM (1997) Human domination of Earth's ecosystems. Science. 277:494-499. https:// doi.org/10.1126/science.277.5325.494

Waltham NJ, Sheaves M (2015) Expanding coastal urban and industrial seascape in the great barrier reef world heritage area: critical need for coordinated planning and policy. Mar Policy 57:78-84

Wicke D, Cochrane TA, O'Sullivan AD (2012) Atmospheric deposition and storm induced runoff of heavy metals from different impermeable urban surfaces. J Environ Manag 14:209-216. https://doi.org/ 10.1039/C1EM10643K

World Harbour Project (2018). http://www.worldharbourproject.org. Accessed 25 May 2017

Yellin, J.M. (2014). Evaluating the efficacy of an artificial floating island as fish habitat in the Chicago River: A pilot study. Thesis. University of Illinois at Urbana-Champaign. 42pp

Zanuttigh B, Angelelli E, Bellotti G, Romano A, Krontira Y, Troianos D, Suffredini R, Franceschi G, Cantù M, Airoldi L, Zagonari F, Taramelli A, Filipponi F, Jimenez C, Evriviadou M, Broszeit S (2015) Boosting blue growth in a mild sea: analysis of the synergies produced by a multi-purpose offshore installation in the northern Adriatic, Italy. Sustainability 7:6804-6853. https://doi.org/10. 3390/su7066804 